\title{
我国典型湖泊及其入湖河流氮磷水质协同控制探讨
}

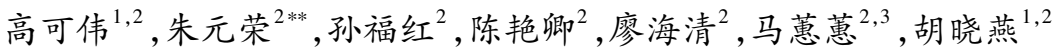 \\ (1: 长江大学地球科学学院,武汉 430100) \\ (2: 中国环境科学研究院,环境基准与风险评估国家重点实验室,北京 100012) \\ (3:西北师范大学地理与环境科学学院, 兰州 730070)
}

\begin{abstract}
摘 要: 人湖河流是外源氮磷输人湖泊的主要途径, 是湖泊外源输人控制的关键中间环节. 本文主要开展我国一些典型 湖泊及其主要人湖河流总氮、总磷浓度对比研究, 结合人湖河流氮磷输人对湖体营养水平和富营养化程度的影响分析, 初步探讨我国人湖河流与湖体氮磷水质协同控制的必要性和途径. 结果表明, 目前人湖河流氮磷水平仍然是我国一些典 型湖泊水体氮磷水平和富营养化程度的重要影响因素之一; 单纯依靠人湖河流氮磷协同控制已经无法较好地实现我国 一些湖泊氮磷水平达到 III 类及以下水平和中营养化水平及以下, 建议结合内源控制、生态修复等综合治理; 除了人湖河 流氮磷水质, 水量也是湖泊水体氮磷水平和富营养化程度的重要因素之一. 进一步结合国际上人湖河流和湖泊氮磷协同 控制, 以及《地表水环境质量标准》(GB 3838-2002) 和相关配套政策、措施等, 最终提出我国人湖河流与湖体氮磷协同控 制政策建议,以期为富营养化湖泊外源氮磷输人控制,湖泊内源治理和生态修复有效开展等提供支撑和依据.
\end{abstract}

关键词: 人湖河流;湖泊;氮;磷;富营养化效应;基准标准;协同控制

\section{A study on the collaborative control of water quality of nitrogen and phosphorus between typical lakes and their inflow rivers in China*}

Gao Kewei ${ }^{1,2}$, Zhu Yuanrong ${ }^{2 * *}$, Sun Fuhong ${ }^{2}$, Chen Yanqing ${ }^{2}$, Liao Haiqing ${ }^{2}$, Ma Huihui ${ }^{2,3} \&$ Hu Xiaoyan ${ }^{1,2}$

(1: School of Earth Science, Yangtze University, Wuhan 430100, P.R. China)

(2: State Key Laboratory of Environmental Criteria and Risk Assessment, Chinese Research Academy of Environmental Sciences, Beijing 100012, P.R.China)

(3: School of Geography and Environmental Science, Northwest Normal University, Lanzhou 730070, P.R. China)

\begin{abstract}
Inflow rivers is the main way for exogenous nitrogen and phosphorus input to lakes, which is also the key transition zone to control the external sources of lakes. Comparative analysis of total nitrogen (TN) and total phosphorus (TP) concentrations of typical lakes and their main inflow rivers from different regions of China was carried out. Based on these analyses, the influence of nitrogen and phosphorus input by the main inflow rivers on the eutrophication of lakes was discussed. Finally, the collaborative control of nutrients of water (TN and TP) between lakes and their inflow rivers was also discussed. Results showed that the exogenous input of TN and TP still had a significant effect on the TN, TP and trophic status index (TSI) of the lakes in China during the 13th Five-Year Plan period. Water quality could not reach class III and maintain mesotrophic status for some lakes in China only by collaborative control of nitrogen and phosphorus between lakes and their inflow rivers. Control of internal load and ecological restoration should also be comprehensively applied to the eutrophication governance of lakes in China. Additionally, the water quality (TN and $\mathrm{TP}$ concentrations) and water volume of inflow rivers have jointly affected on the TN and TP concentrations and TSI of the lake in China. Based on the measures, regulations and laws from other developed countries, also combined with the present situation of water quality of lakes and their inflow rivers, policy and proposal about collaborative control on nitrogen and phosphorus of lakes and
\end{abstract}

* 2020-12-03 收稿;2021-03-01 收修改稿.

国家水体污染控制与治理科技重大专项 (2018ZX07208001) 和国家自然科学基金项目 (41877380)联合资助.

** 通信作者;E-mail:zhuyuanrong07@ mails.ucas.ac.cn. 
their inflow rivers was proposed. This research would support the control of exogenous nitrogen and phosphorus and ecological restoration for eutrophic lakes in China.

Keywords: Inflow rivers; lakes; nitrogen; phosphorus; eutrophication; criteria and standards; collaborative control

湖泊是地表生态系统各要素相互作用的节点, 是地球上重要的淡水资源库、物种基因库和洪水调蓄库 等,与人类的生产、生活息息相关 ${ }^{[1]}$. 我国湖泊众多,分布广泛,目前共有 $1.0 \mathrm{~km}^{2}$ 以上的自然湖泊约为 2693 个,分布在 28 个省 (自治区、直辖市), 总面积 8.1 万 $\mathrm{km}^{2}$, 约占国土面积的 $0.9 \%{ }^{[1]}$. 这些湖泊具有非常重要 的价值,例如为人类提供生活饮用水、农业灌溉水等可利用价值; 维持一些重要生态价值及为生物提供栖息 地; 甚至一些湖泊拥有非常重要的文化和宗教价值 ${ }^{[2]}$. 与河流相比, 湖泊一般具有 3 个基本特征,包括集成 性、换水周期长和复杂的反应动力学,这些特征也相对容易导致氮磷等营养盐汇聚、累积, 从而导致多数湖 泊较易富营养化和暴发蓝藻水华 ${ }^{[3]}$. 湖泊流域经济快速发展和人类活动加剧, 进一步导致氮磷等营养盐大 量输人湖体并长期累积于沉积物和生物体等, 从而极大加速了湖泊富营养化进程和生态系统结构等变化. 目前,富营养化也已经成为我国湖泊面临的主要生态环境问题之一 ${ }^{[4]}$.

外源氮、磷营养盐负荷的输人, 例如含氮磷生活、工农业生产废水的输人等, 是引起湖泊氮磷负荷急剧 增加并引起蓝藻水华暴发的主要因素之一 ${ }^{[5-7]}$. 近年来我国对外源氮磷的输人负荷, 尤其是点源输人负荷控 制取得了积极成效 ${ }^{[8]}$, 湖泊富营养化及蓝藻水华治理需要进一步协同开展外源削减、内源控制以及生态修 复 ${ }^{[9-12]}$. 其中, 外源氮磷输人进一步严格控制, 可能仍是我国一些湖泊, 尤其是一些国控重点湖泊富营养化治 理的长期和首要任务, 是其他途径有效治理的前提和基本保障. 河流是点源、面源输人湖泊的中间过程和重 要纽带, 点源、面源基本通过人湖河流汇聚并最终输人至湖泊 ${ }^{[13]}$. 例如, 我国大型浅水湖泊、流域内河网密 布的太湖,其主要人湖河流污染输人负荷可占人湖污染负荷总量的 70\% 80\% ${ }^{[14]}$.

一般而言, 河流、湖泊在地形地貌和基本属性等方面存在较明显差异 ${ }^{[15-16]}$, 尤其是水动力、水力停留时 间、分层等,最终体现在生物对氮、磷等营养盐的响应存在显著差异 ${ }^{[15]}$. 因此, 河流、湖泊制定氮、磷基准或 标准的方法不同或最终限值上差别较大, 河流、湖泊的氮、磷基准或标准限值一般分别制定 ${ }^{[17-18]}$. 目前, 国际 上如美国 ${ }^{[19]}$ 、英国 ${ }^{[20-21]}$ 、加拿大 ${ }^{[22-23]}$ 、日本 ${ }^{[24]}$ 和韩国 ${ }^{[25]}$ 等国家制定的河流、湖泊氮磷的基准或标准限值中 并未直接体现人湖河流与湖泊水体氮磷水质协同控制, 而是分别制定适合河流和湖泊保护的氮磷水质基准 或标准限值. 我国现行《地表水环境质量标准》( GB 3838-2002) 中地表水质量标准基本项目标准限值一栏 中规定了河流、湖库各类别水质标准限值, 是我国湖泊流域河流、湖泊氮、磷控制的基本依据. 依据不同水 体、功能和生物响应等,基于科学研究基础和社会经济条件等, 分别制定河流和湖泊水体氮、磷基准或标准 限值是必要的.

关于人湖河流、湖库和不直接流人湖库河流总磷 (TP) 控制阈值, Mackenthun ${ }^{[26]}$ 指出为防止水体富营养 化, 不直接流人湖库河流 TP 理想的目标是 $0.1 \mathrm{mg} / \mathrm{L}$ 以下; 人湖 (库) 河流在其流人处 TP 浓度不得超过 0.05 $\mathrm{mg} / \mathrm{L}$; 湖库水体 TP 浓度不得超过 $0.025 \mathrm{mg} / \mathrm{L}$. 显然, 人湖河流具有特殊性, 而且其输人的外源氮磷与湖体氮 磷浓度、富营养化程度和蓝藻水华暴发等往往紧密联系 ${ }^{[26]}$. 因此, 人湖河流氮磷控制应该充分考虑下游湖 泊富营养化控制和生态保护需求, 并执行比一般河流更为严格的限值. 例如美国环境保护局 (EPA) 颁布的 河流与湖泊营养物基准制定指南中均提出了该要求,并通过日最大负荷 (TMDL) 计划等配套措施实现湖泊 及其人湖河流营养盐协同控制 ${ }^{[27-28]}$. 目前, 我国现行《地表水环境质量标准》(GB 3838-2002) 中对河流、湖 泊水体的总氮 ( TN)、总磷 (TP) 标准限值的规定差异较大. 以地表水 III 类水质控制目标为例: 河流 $\mathrm{TP} \leqslant 0.2$ $\mathrm{mg} / \mathrm{L}, \mathrm{TN}$ 未作要求; 湖体 $\mathrm{TP} \leqslant 0.05 \mathrm{mg} / \mathrm{L}, \mathrm{TN} \leqslant 1.0 \mathrm{mg} / \mathrm{L}$. 为了防治湖库富营养化, 与之相互配套发布了《湖 库富营养化防治技术政策》(环发 [2004]59 号), 但是《地表水环境质量标准》(GB 3838-2002) 中河流、湖 泊 TN、TP 标准限值仍然是考核基本依据. 已有研究表明, 如果同样以 III 类水质为人湖河流和湖泊水体控制 标准, 基于湖泊水体 III类水质控制目标, 太湖西北部人湖河流 TN 协同控制限值应该设定在 $1.5 \sim 1.6 \mathrm{mg} / \mathrm{L}$ 之间, TP 协同控制限值设定在 $0.071 \sim 0.090 \mathrm{mg} / \mathrm{L}$ 之间 ${ }^{[29]}$; 鄱阳湖主要人湖河流 TN 的控制限值应该设定在 $1.2 \mathrm{mg} / \mathrm{L}$, TP 的控制限值设定为 $0.075 \mathrm{mg} / \mathrm{L}^{[30]}$; 阳澄湖人湖河流 TN 的控制限值应该设定在 $1.64 \sim 1.96 \mathrm{mg} /$ $\mathrm{L}$, TP 的控制限值设定为 $0.060 \sim 0.076 \mathrm{mg} / \mathrm{L}^{[31]}$. 显然, 如果仅以现行《地表水环境质量标准》( GB $3838-$ 
2002) 中 III类标准为湖泊及其人湖河流水质控制目标, 河流的氮、磷控制标准可能难以满足湖体氮、磷控制 需求,对富营养化湖泊外源氮、磷输人有效控制十分不利 ${ }^{[29-31]}$.

本研究基于 “十三五” 期间我国一些典型湖泊及其人湖河流 TN 、TP 浓度差异, 以及《地表水环境质量标 准》(GB 3838-2002) 执行以来, 我国大型浅水湖泊太湖人湖河流、湖体 TN、TP 浓度历史差异、水量变化以 及氮磷输人负荷历史变化, 分析我国人湖河流氮、磷输人对湖泊水体中氮、磷浓度和富营养化程度的影响, 以此分析我国湖泊及其人湖河流氮、磷输人协同控制的必要性; 结合国内外关于人湖河流氮、磷控制相关法 律法规、指南和研究现状等, 初步探讨我国人湖河流和湖体氮、磷协同控制途径并提出可能的政策建议, 以 期为富营养化湖泊外源氮、磷输人负荷进一步科学控制和《地表水环境质量标准》修订提供支撑和依据.

\section{1 材料与方法}

\section{1 研究区域}

基于 “十三五” 期间, 我国开展水质监测的 110 个重要湖泊中选取了不同区域、数据较完整的湖泊及其 对应的主要人湖河流. 针对现行《地表水环境质量标准》( GB 3838-2002) 执行以来, 人湖河流与湖泊水体 $\mathrm{TN} 、 \mathrm{TP}$ 水质指标的历史变化趋势及其对比分析, 选取数据较丰富、我国重点治理的大型浅水湖泊太湖及其 主要人湖河流为代表性研究对象. 本研究涉及的我国典型湖泊及其主要人湖河流详细信息见表 1 .

表 1 研究涉及的我国典型湖泊及其主要人湖河流

Tab.1 Selected typical lakes and their main inflow rivers of China in this study

\begin{tabular}{|c|c|c|c|}
\hline 区域 & 编号 & 重点湖泊 & 主要人湖河流 \\
\hline 蒙新湖区 & L1 & 博斯腾湖 & 开都河 \\
\hline \multirow[t]{3}{*}{ 云贵高原湖区 } & $\mathrm{L} 2$ & 滇池 & 盘龙江、西坝河、洛龙河、马料河、东大河等 35 条人湖河流 \\
\hline & L3 & 洱海 & 弥苴河 \\
\hline & $\mathrm{L} 4$ & 红枫湖 & 羊昌河 \\
\hline 东北平原与山丘湖区 & L5 & 镜泊湖 & 牡丹江干流 \\
\hline \multirow[t]{6}{*}{ 东部平原湖区 } & L6 & 巢湖 & 柘者河、裕溪河、南淝河、十五里河 \\
\hline & L7 & 太湖 & 百渎港、大港河、望虞河等 22 条人湖河流 \\
\hline & L8 & 洞庭湖 & 湘江、资水、沅江、澧水 \\
\hline & L9 & 鄱阳湖 & 赣江、抚河、信江、饶河、修水 \\
\hline & L10 & 南四湖 & 洙赵新河、东渔河、泗河、白马河 \\
\hline & L11 & 洪泽湖 & 淮河、新泣河、怀洪新河、老泣河、新滩河、潍河、徐洪河 \\
\hline
\end{tabular}

\section{2 数据收集与来源}

“十三五” 期间, 研究涉及的典型湖泊及其对应的主要人湖河流 TN 、TP 数据来源于生态环境部国家地 表水环境监测数据. 湖泊综合富营养化指数 $(T L I(\Sigma))$ 等数据和信息来源于生态环境部历年发布的《中国 环境状况公报》和《中国生态环境状况公报》,或者湖泊所在省、市官方公开的《生态环境状况公报》等. “十 三五” 期间, 主要是 2016-2019 年月监测数据, 其中 2019 年一些月份监测数据缺失, 统计分析中仅以部分月 份数据为统计分析依据, 由于月份差异不是十分明显, 对总体规律分析影响不大.

另外, 2003 年以来, 太湖及其人湖河流 TN 和 TP 水质、输人负荷以及水量等历史数据来源于太湖流域 管理局公开的数据及基于太湖流域管理局水质和水量监测数据发表的相关文献资料 ${ }^{[32-33]}$. 近年来太湖及其 主要人湖河流 TN、TP 水质数据采用生态环境部国家地表水环境监测数据. 太湖流域管理局与生态环境监测 部门来源的 TN、TP 水质数据差异对总体变化趋势、相互关系等研究影响较小.

\section{3 数据处理与统计分析}

同一湖泊水体涉及多个点位监测数据, 采用算术平均值方式统计分析该湖泊水体监测数值的平均值; 同一湖泊对应多条人湖河流, 均统计分析其算术平均值. 平均值计算样本中的变化范围采用标准偏差 (SD) 表示. 利用 Origin 2018 软件开展相关性分析, 并采用 Pearson 系数 (双尾检验) 进行相关性分析. 柱状图、散 点图及其对应趋势线等采用 Excel 2019 软件作图及分析. 


\section{2 结果与分析}

\section{1 “十三五”期间我国典型湖泊及其主要入湖河流氮磷水质对比分析}

2.1.1 入湖河流与湖泊水体氮磷水平总体对比分析 近些年来, 研究涉及的我国典型湖泊主要人湖河流 TN、 $\mathrm{TP}$ 平均浓度基本较对应湖泊高, 尤其是滇池、巢湖和太湖人湖河流 TN 、 TP 浓度较高 (图 1). 其中, 湖泊 TN 浓度变化范围大, 介于 $0.55 \sim 2.20 \mathrm{mg} / \mathrm{L}$ 之间, 处于湖泊水质 II V 类; 对应主要人湖河流 $\mathrm{TN}$ 浓度均值介于 $0.84 \sim 6.37 \mathrm{mg} / \mathrm{L}$ 之间. 这些典型湖泊水体 TP 浓度介于 $0.01 \sim 0.10 \mathrm{mg} / \mathrm{L}$ 之间, 处于湖泊水质的 II $\sim \mathrm{IV}$ 类, 对 应主要人湖河流 TP 浓度介于 $0.01 \sim 0.19 \mathrm{mg} / \mathrm{L}$ 之间, 属于河流水质 I III类. 显然, 单纯从水质类别上分析, 人湖河流氮磷水质控制要优于湖泊水体. 然而, 从二者 TN TP 实际浓度差异对比分析, 表明人湖河流 TN 浓 度是对应湖泊水体的 $0.96 \sim 3.09$ 倍, TP 浓度是对应湖泊水体的 $0.46 \sim 2.18$ 倍. 另外, 与湖泊水体 TN、TP 浓度 相比,其对应人湖河流 TN、TP 浓度时空变化范围较大, 即图 1 中误差变化范围相对较大.
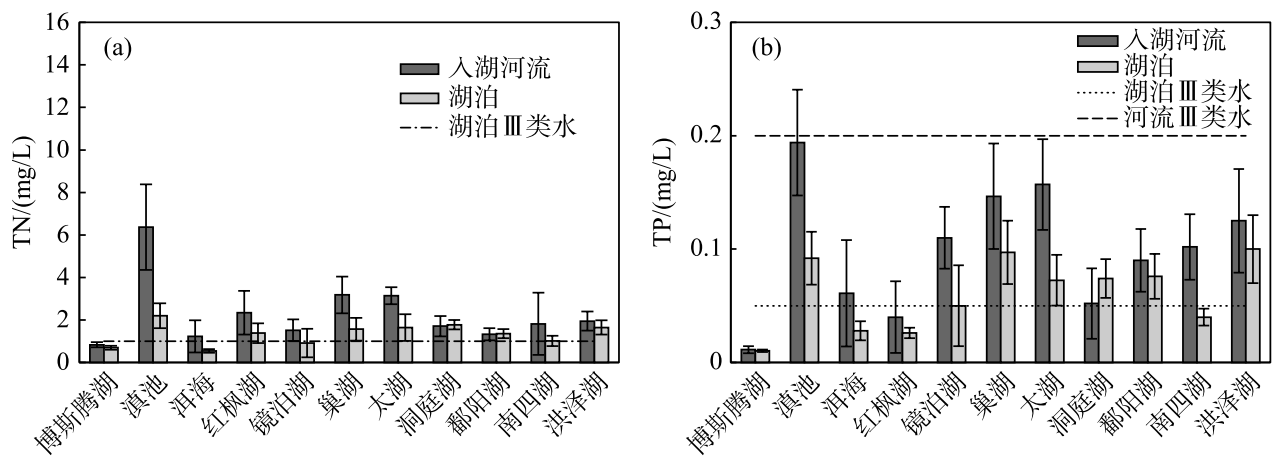

图 1 “十三五”期间我国典型湖泊及其主要人湖河流氮、磷营养盐对比分析

Fig.1 Comparative analysis of TN and TP of lakes and their inflow rivers during the 13th Five-Year Plan period

进一步分析结果表明, 研究所涉及的这些典型湖泊 TN 、TP 浓度与其对应的主要人湖河流 TN TP 浓度 呈显著正相关 (图 2a,b). “十三五” 期间, 我国一些典型湖泊主要人湖河流氮磷输人仍然对湖泊水体氮磷水 平具有直接的影响, 进而对湖泊富营养化水平产生了显著影响 (图 2c, d), 即随着人湖河流 TN、TP 浓度的上 升, 湖体 $T L I(\Sigma)$ 显著升高.

2.1.2 不同区域典型湖泊水体与入湖河流氮磷浓度关系的对比分析 以本研究涉及的东部平原湖区与云贵 高原湖区的典型湖泊为例, 发现不同地域典型湖泊与人湖河流氮磷浓度的相互关系存在一定差异 (图 3,4). 基于线性统计分析而言, 涉及的东部平原湖区典型湖泊 $\mathrm{TN}$ 浓度 $(y)$ 与人湖河流 $\mathrm{TN}$ 浓度 $(x)$ 的响应关系为: $y=0.1022 x+1.2749(P<0.05)$; TP 浓度的响应关系为: $y=0.2397 x+0.0515(P<0.05)$. 云贵高原湖区典型湖泊 $\mathrm{TN}$ 浓度 $(y)$ 与人湖河流 TN 浓度 $(x)$ 的响应关系为: $y=0.239 x+0.5822(P<0.01)$; TP 浓度的响应关系为: $y=$ $0.375 x+0.0108(P<0.01)$. 以此为依据, 东部平原湖区典型湖泊和云贵高原典型湖泊达到《地表水环境质量 标准》( GB 3838-2002) 不同 TN、TP 水质类别,推算人湖河流协同控制目标值详见表 2. 涉及的东部平原湖 区和云贵高原湖区典型湖泊, 不同湖泊水体 TN、TP 水质类别, 人湖河流协同控制目标值可能存在较大差异. 仅仅通过河湖氮、磷协同控制, 东部平原湖区这些典型湖泊可能难以达到湖泊水体 TN、TP 的 III类水质标准, 云贵高原湖区这些典型湖泊可能可以达到较好的效果.

进一步分析表明,在同一湖区内的典型湖泊之间也存在河湖响应关系的明显差异 (图 3,4). 例如在东 部平原湖区, 南四湖与其他长江中下游湖泊 TN 、TP 浓度对人湖河流 TN 、 TP 浓度的响应规律差异较大 (图 3). 在云贵高原湖区, 滇池人湖河流 TN 、P 浓度变化对湖泊水体 TN、TP 浓度具有决定性作用, 然而红枫湖 和洱海人湖河流 TN、TP 浓度变化对湖泊水体 TN、TP 浓度的影响程度相对较小 (图 4). 

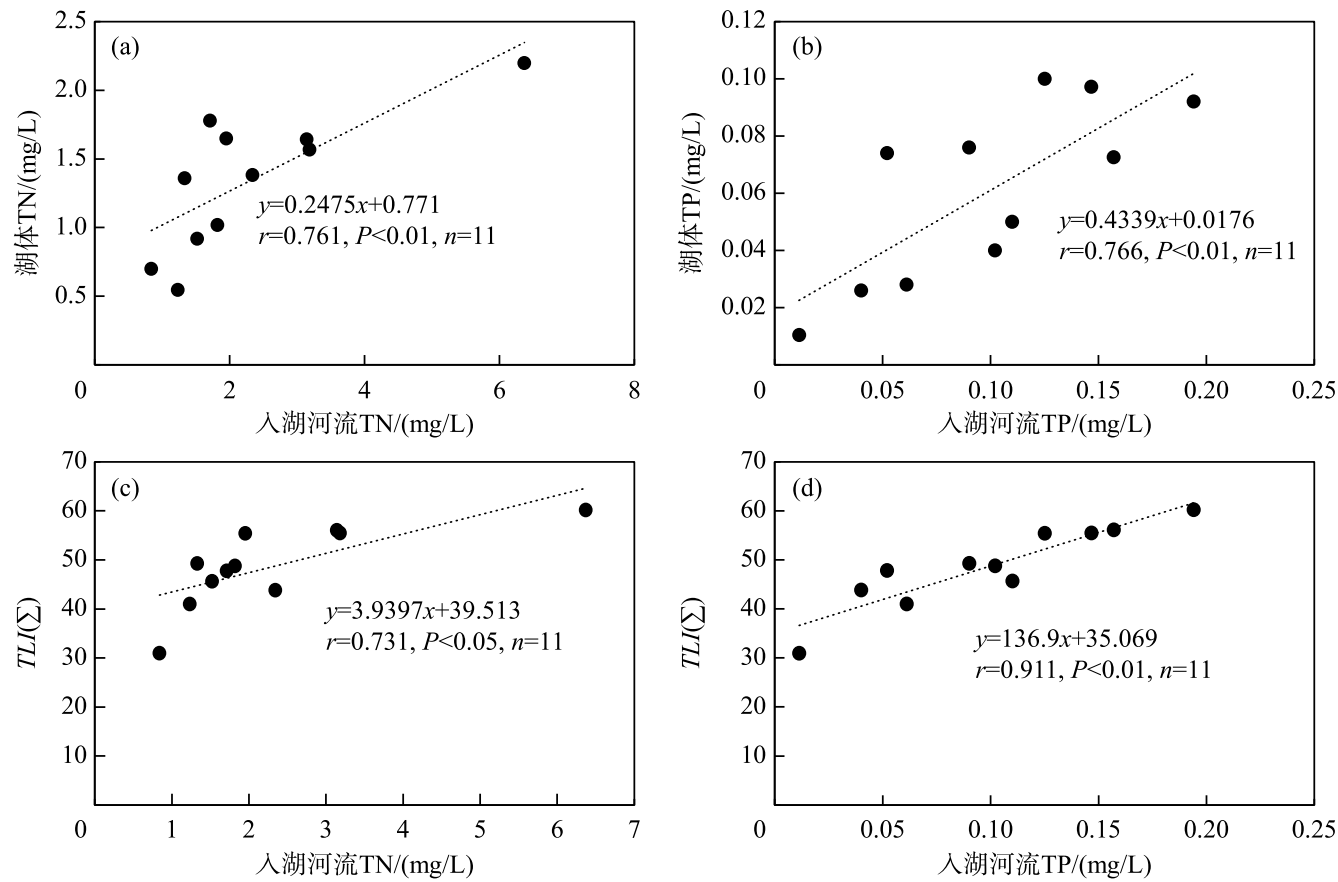

图 2 “十三五” 期间我国典型湖泊及主要人湖河流氮磷营养盐对湖体 TN、TP 和 $T L I\left(\sum\right)$ 的影响

Fig.2 Influence of TN, TP concentrations of main inflow rivers on TN, TP and $\operatorname{TLI}(\Sigma)$ of typical lakes during the 13th Five-Year Plan period

表 2 基于线性关系推算东部平原湖区和云贵高原湖区典型湖泊人湖河流协同控制目标值

Tab.2 Target values of TN and TP for collaborative control between typical lakes and their inflow rivers in the eastern plain and the Yunnan-Guizhou plateau of China

\begin{tabular}{|c|c|c|c|c|c|}
\hline \multicolumn{3}{|c|}{$\mathrm{TN} /(\mathrm{mg} / \mathrm{L})$} & \multicolumn{3}{|c|}{$\mathrm{TP} /(\mathrm{mg} / \mathrm{L})$} \\
\hline $\begin{array}{c}\text { GB } 3838-2002 \\
\text { 标准限值 }\end{array}$ & \multicolumn{2}{|c|}{ 推算人湖河流协同控制目标值 } & $\begin{array}{c}\text { GB } 3838-2002 \\
\text { 标准限值 }\end{array}$ & \multicolumn{2}{|c|}{ 推算人湖河流协同控制目标值 } \\
\hline $\begin{array}{c}\text { 湖泊水质类别 } \\
\text { (限值) }\end{array}$ & $\begin{array}{c}\text { 东部平原湖区 } \\
\text { 典型湖泊 }\end{array}$ & $\begin{array}{c}\text { 云贵高原湖区 } \\
\text { 典型湖泊 }\end{array}$ & $\begin{array}{c}\text { 湖泊水质类别 } \\
\text { (限值) }\end{array}$ & $\begin{array}{c}\text { 东部平原湖区 } \\
\text { 典型湖泊 }\end{array}$ & $\begin{array}{c}\text { 云贵高原湖区 } \\
\text { 典型湖泊 }\end{array}$ \\
\hline $\mathrm{I}$ 类 $(0.2)$ & - $^{*}$ & - & I 类 $(0.01)$ & - & - \\
\hline II 类 $(0.5)$ & - & - & II 类 $(0.025)$ & - & 0.038 \\
\hline III类 ( 1 ) & - & 1.75 & III类 $(0.05)$ & - & 0.105 \\
\hline IV类 ( 1.5$)$ & 2.20 & 3.84 & $\mathrm{IV}$ 类 $(0.1)$ & 0.202 & 0.238 \\
\hline $\mathrm{V}$ 类 $(2)$ & 7.09 & 5.93 & $\mathrm{~V}$ 类 $(0.2)$ & 0.620 & 0.505 \\
\hline
\end{tabular}

* 推算目标值小于 0 , 即无法单独通过入湖河流 TN 、TP 控制达到湖体水质控制目标.

\section{2 典型湖泊及其入湖河流氮磷控制历史变化趋势对比分析一以太湖为例}

2.2.1 主要入湖河流和湖体 TN、TP 历史变化趋势及其对太湖富营养化的影响分析 总体而言, 我国现行《地 表水环境质量标准》( GB 3838-2002) 执行以来, 环太湖主要人湖河流 TN、TP 浓度呈显著下降趋势 $(\mathrm{TN}: r=$ $-0.907, P<0.01, n=16$; TP : $r=-0.723, P<0.05, n=16)$, 太湖水体 TN 浓度呈显著下降趋势 $(r=-0.957, P<$ $0.01, n=16)$, 而 TP 浓度波动明显且无显著下降或上升趋势 $(r=-0.219, P>0.05, n=16) .2003-2019$ 年期 间, 太湖水体 $\mathrm{TN}$ 浓度变化范围为 $1.34 \sim 3.17 \mathrm{mg} / \mathrm{L}$, 均值为 $2.28 \mathrm{mg} / \mathrm{L}$, 其人湖河流 $\mathrm{TN}$ 浓度变化范围为 $2.67 \sim$ 

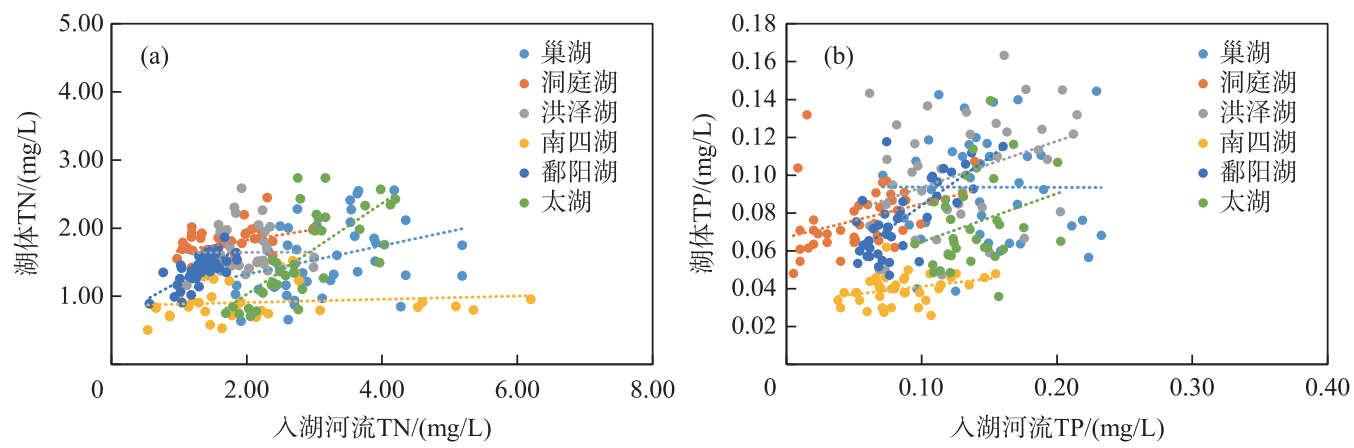

图 3 “十三五”期间我国东部平原湖区湖泊水体氮磷浓度与其主要人 湖河流氮磷浓度的相互关系 (月监测数据)

Fig.3 Relationships between nutrients ( TN and TP) of lakes and their main inflow rivers in the eastern plateau of China during the 13th Five-Year Plan period (monthly monitoring data)
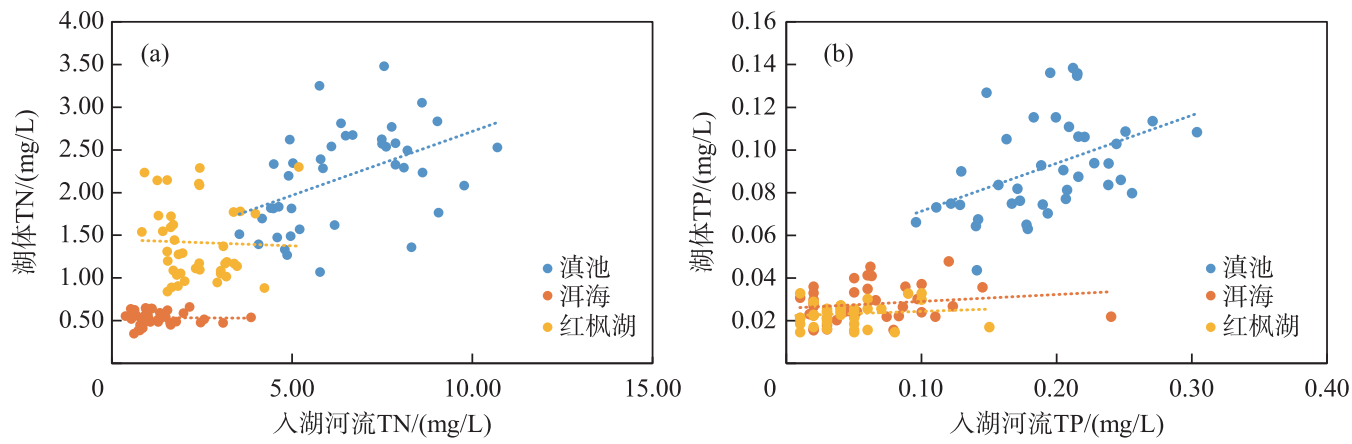

图 4 “十三五” 期间我国云贵高原湖区湖泊水体氮磷浓度及人湖河流氮磷浓度的相互关系 (月监测数据)

Fig.4 Relationships between nutrients ( TN, TP) of lakes and their main inflow rivers in the

Yunnan-Guizhou plateau of China during the 13th Five-Year Plan period (monthly monitoring data)

$5.65 \mathrm{mg} / \mathrm{L}$, 均值为 $4.11 \mathrm{mg} / \mathrm{L}$ (图 5). 人湖河流与太湖水体 TN 浓度比值变化不大, 主要人湖河流 TN 年均浓 度约为太湖水体 TN 年均浓度的 1.5 2.3 倍, 这表明 GB 3838-2002 执行以来, 环太湖人湖河流 TN 浓度与 湖体 TN 浓度差异倍数或者响应关系基本保持稳定. 太湖水体 TP 浓度变化范围为 $0.056 \sim 0.102 \mathrm{mg} / \mathrm{L}$, 均值 为 $0.075 \mathrm{mg} / \mathrm{L}$, 人湖河流 TP 浓度变化范围为 $0.125 \sim 0.233 \mathrm{mg} / \mathrm{L}$,均值为 $0.173 \mathrm{mg} / \mathrm{L}$, 人湖河流与湖区 $\mathrm{TP}$ 浓 度对比倍数历史变化较大, 介于 1.5 2.9 之间, 尤其是 2015 年以来变化较大 (图 5). 这是由于 2015 以来, 人 湖河流 TP 浓度稳中有降, 而太湖水体 TP 浓度却连续上升, 综合因素导致人湖河流与太湖水体 TP 浓度比值 突然下降. 这可能是由于 2015 和 2016 年丰水年导致大量外源磷输人并在太湖沉积物中累积, 以及 2015 年 沉水植物收割和水深增加引起沉水植物的减少, 进而导致对磷吸收转化能力下降等导致湖体 TP 浓度异常 升高 ${ }^{[14]}$. 这些因素可能对太湖流域河、湖氮磷协同控制问题提出了更高的要求, 即为了太湖 TP 控制达到某 一目标, 需要对人湖河流 TP 浓度执行更严格限值.

现行《地表水环境质量标准》(GB 3838-2002) 执行以来, 人湖河流 TN 浓度可能一直是太湖水体 TN 浓 度的主要影响因素 (图 6a), 而人湖河流 TP 浓度对太湖水体 TP 浓度的影响比较复杂(图 6b), 这可能是由 于内源磷不稳定释放等其他输人因素影响较大. 与太湖水体氮磷对人湖河流氮磷的响应不同, 太湖水体 $T L I(\Sigma)$ 对人湖河流 TN、TP 浓度具有显著的响应关系 (图 6c,d). 这表明, 虽然太湖水体 TP 浓度与人湖河流 $\mathrm{TP}$ 浓度的响应关系复杂, 但是人湖河流输人磷却是太湖富营养化的关键影响因素之一, 说明单纯太湖人湖 河流氮、磷水质的提升对太湖富营养化程度的改善具有非常重要的作用. 

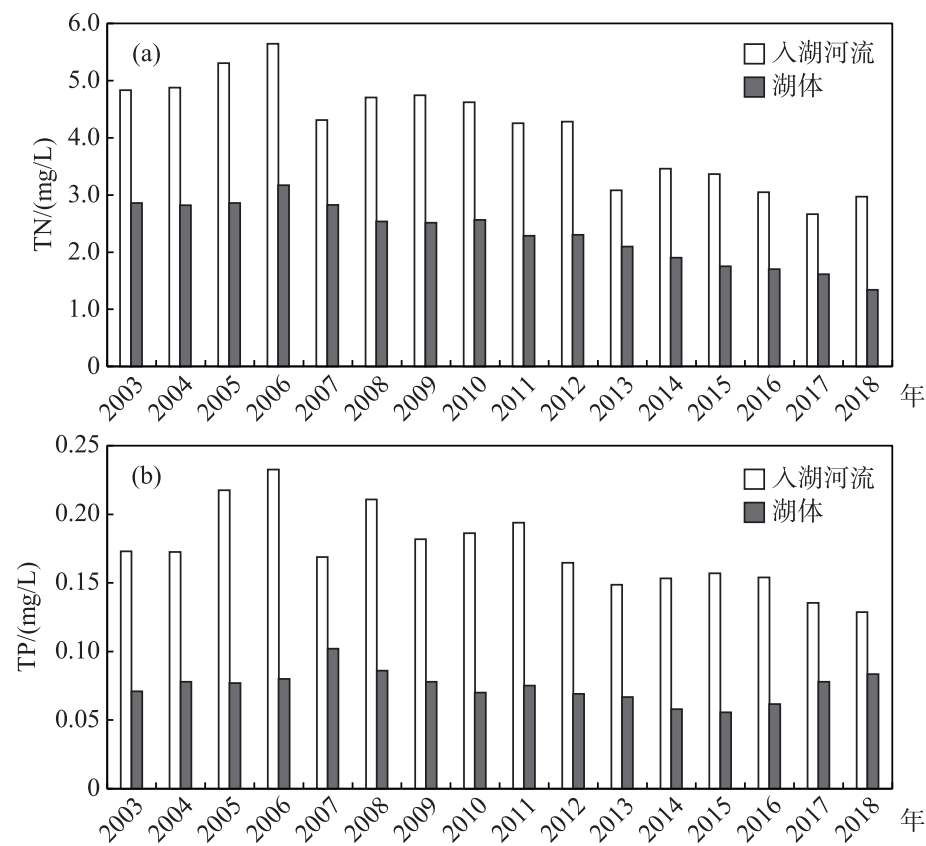

图 5 太湖 2003-2019 年人湖河流与湖体 TN、TP 浓度变化趋势对比分析

Fig.5 Variation of TN and TP concentrations in overlying water of Lake Taihu and the main inflow rivers from 2003 to 2019
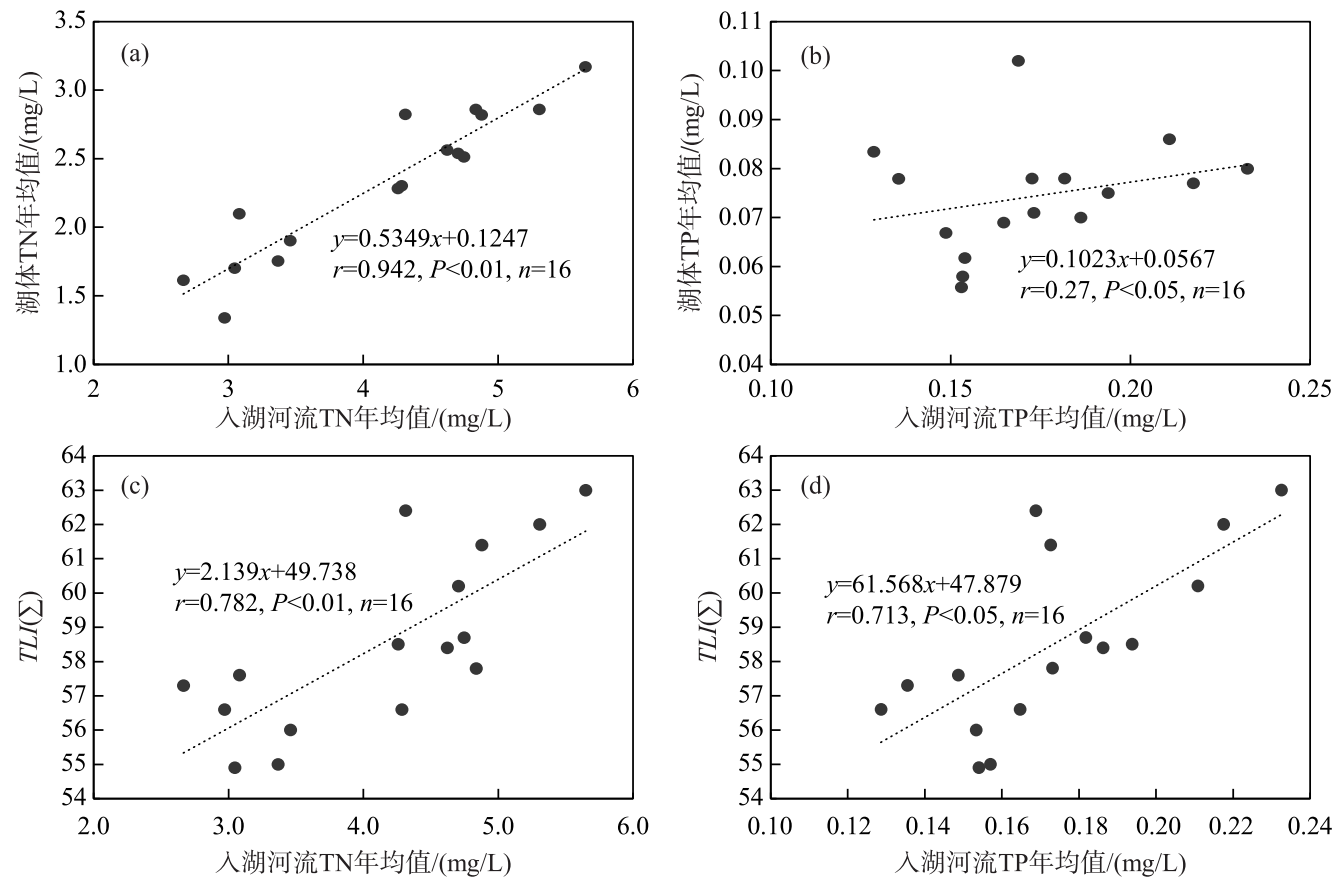

图 6 现行《地表水环境质量标准》( GB 3838-2002) 执行以来环太湖

主要人湖河流氮磷水质对湖体 TN、TP 和 $T L I\left(\sum\right)$ 的影响

Fig.6 Influence of TN, TP concentrations of the main inflow rivers on TN, TP concentrations and $T L I(\Sigma)$ of Lake Taihu from the year 2003 
2.2 .2 水量变化对太湖流域入湖河流氮磷输入负荷、湖体氮磷水质及 $T L I\left(\sum\right)$ 的影响分析 2003 年以来,太湖 人湖水量变化与 TN、TP 浓度变化趋势相反,即人湖水量呈现显著上升趋势 (图 7). 人湖河流水量增加抵消了 氮、磷水质变化对输人负荷的影响, 即太湖 TN、TP 输人负荷并未随着 $\mathrm{TN}$ 、 $\mathrm{TP}$ 水质改善而发生明显的下降趋势 (图 8). 进一步分析表明, 人湖河流氮磷负荷与 $T L I\left(\sum\right)$ 并无显著相关关系 $(\mathrm{TN}: r=-0.246, P>0.05, n=16$; TP: $r=-0.398, P>0.05, n=16)$. 人湖河流 TN 、TP 年输人负荷变化具有一致性 $(r=0.872, P<0.01, n=16)$, 这表明二 者来源、影响因素等可能高度一致,但是输人湖体后对湖体氮、磷浓度的影响有明显的差异 (图 9).

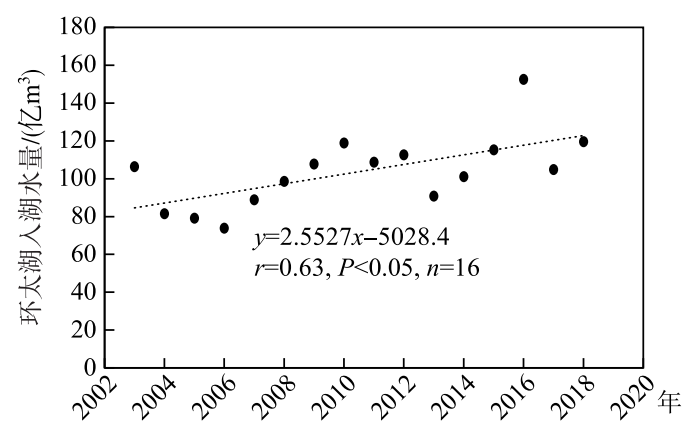

图 $72003-2018$ 年环太湖人湖水量变化趋势

Fig.7 Variation trend of total volume of the main inflow water of Lake Taihu from 2003 to 2018

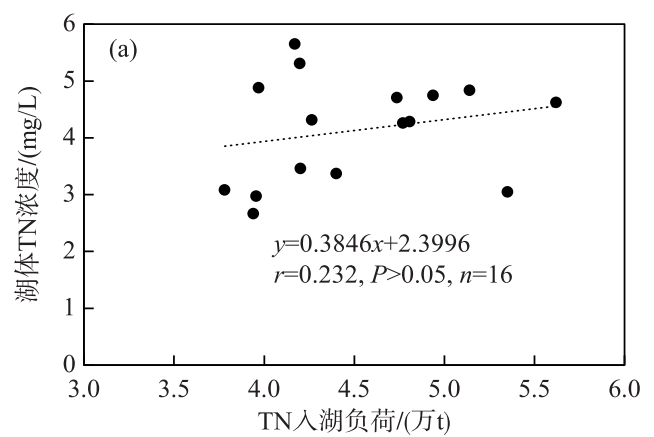

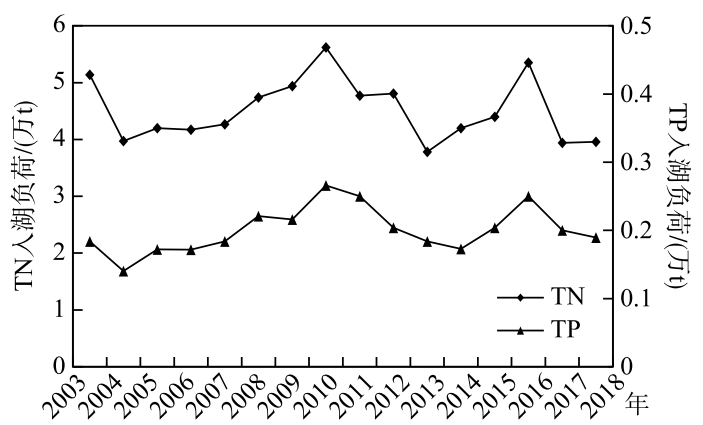

图 8 2003-2018 人湖河流 TN、TP 污染负荷变化趋势

Fig. 8 Variation trend of TN and TP load of inflow to Lake Taihu from 2003 to 2018

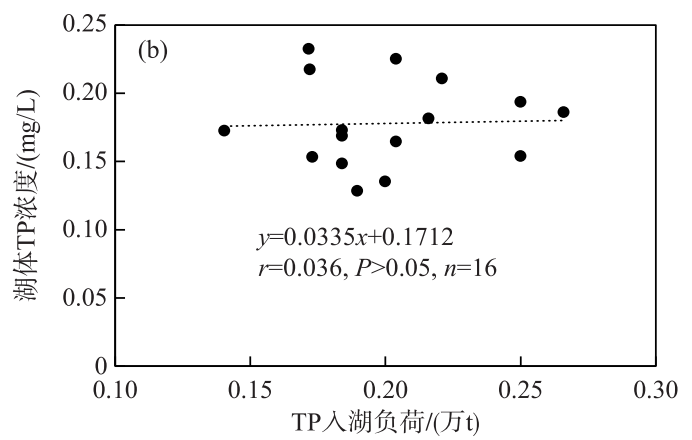

图 9 太湖 2003-2018 年人湖河流 TN、TP 污染负荷与太湖水体 TN、TP 浓度的关系

Fig.9 Relationship between TN and TP loads and TN and TP concentrations in overlying water from Lake Taihu water from 2003 to 2018

人湖河流水量变化不仅仅是影响 TN 、TP 输人负荷的关键因素之一,也对湖 泊水体本身 TN、TP 浓度的下降具有显著 的作用 (表 3). 这可能是由于氮磷水质的 提升, 水量增加, 有利于缩短湖泊水体换 水周期,加快湖体污染物的稀释和自净, 提高出湖氮磷通量等. 进一步分析表明, 与单纯氮磷水质提升相似, 水量的增加对 湖泊水体的 $T L I(\Sigma)$ 也具有显著的改善 作用 (表 3 ). 因此,水质和水量协同控制, 可能是太湖营养盐和富营养化程度进一 步有效控制和改善的重要手段.
表 $32003-2018$ 年人湖水量与湖泊水体 TN 、TP 浓度、 输人负荷之间的相关性分析 $(n=16)$

Tab.3 Correlation of total volume of the main inflow water with TN, TP concentrations, $T L I(\Sigma)$ and input loads of Lake Taihu

\begin{tabular}{ccc}
\hline & \multicolumn{2}{c}{ 太湖人湖河流水量 } \\
\cline { 2 - 3 } & $P$ & $r$ \\
\hline 湖体 TN 浓度 & $<0.01$ & -0.65 \\
湖体 TP 浓度 & $<0.05$ & -0.62 \\
$\mathrm{TN}$ 输人负荷 & 0.61 & 0.14 \\
$\mathrm{TP}$ 输人负荷 & $<0.05$ & 0.62 \\
$T L I\left(\sum\right)$ & $<0.01$ & -0.80 \\
\hline
\end{tabular}




\section{3 讨论}

\section{1 入湖河流氮磷输入对我国典型湖泊水质和富营养化的影响}

基于现行《地表水环境质量标准》, 单纯从水质类别评价, 目前我国典型湖泊流域内人湖河流 TN、TP 水 质类别优于湖泊水体, 其中 TN 无限值规定. 但是, 总体、区域和历史数据的统计分析均表明我国典型湖泊流 域主要人湖河流氮磷浓度水平和输人负荷对湖泊水体 TN、TP 水平及其富营养化具有显著的影响. 这表明结 合《地表水环境质量标准》, 进一步开展我国人湖河流与湖泊氮磷协同控制十分必要和紧迫. 基于我国一些 典型湖泊的 $T L I(\Sigma)$ 与人湖河流 TN、TP 浓度的拟合线性响应方程 (图 2), 表明湖泊不同营养水平控制目 标, 对应人湖河流 TN、TP 浓度需要控制到一个合理水平 (表 4). 总体而言, 如果我国一些典型湖泊营养状态 控制在轻度富营养化水平以下, 人湖河流 TN 浓度可能需要控制在 $2.66 \mathrm{mg} / \mathrm{L}$ 以下, TP 浓度控制在 0.109 $\mathrm{mg} / \mathrm{L}$ 以下. 另外, 随着我国湖泊氮磷输人长期累积、湖泊生态结构改变等, 单纯依靠人湖河流氮磷控制可能 难以使一些典型湖泊达到中营养水平以下.

表 4 基于我国典型湖泊不同营养水平控制目标的人湖河流氮磷协同控制限值

Tab.4 Limited values of TN and TP of inflow rivers for different trophic status of typical lakes in China

\begin{tabular}{ccc}
\hline 预期营养状态控制目标 & $\mathrm{TN} /(\mathrm{mg} / \mathrm{L})$ & $\mathrm{TP} /(\mathrm{mg} / \mathrm{L})$ \\
\hline$T L I\left(\sum\right)<30$ (贫营养) & - & - \\
$30 \leqslant T L I\left(\sum\right) \leqslant 50$ (中营养 $)$ & $0<\mathrm{TN} \leqslant 2.66$ & $0<\mathrm{TP} \leqslant 0.109$ \\
$T L I\left(\sum\right)>50$ (富营养) & $\mathrm{TN}>2.66$ & $\mathrm{TP}>0.109$ \\
$50<T L I\left(\sum\right) \leqslant 60$ (轻度富营养) & $2.66<\mathrm{TN} \leqslant 5.20$ & $0.109<\mathrm{TP} \leqslant 0.182$ \\
$60<T L I\left(\sum\right) \leqslant 70$ (中度富营养) & $5.20<\mathrm{TN} \leqslant 7.74$ & $0.182<\mathrm{TP} \leqslant 0.266$ \\
$T L I\left(\sum\right)>70$ (重度富营养) & $\mathrm{TN}>7.74$ & $\mathrm{TP}>0.266$ \\
\hline
\end{tabular}

与人湖河流 TN 相比, 人湖河流 TP 输人对湖泊水体 TP 浓度的影响较大, 对湖泊水体富营养化程度的影 响更显著 (图 2). 这可能与河湖连续系统氮、磷不同生物地球化学过程密切相关 ${ }^{[34-35]}$. 入湖河流输人的部分 氮在湖体内通过反硝化作用, 最终以氮气的形式返回于大气. 相比之下, 人湖河流输入磷, 仅能通过出湖水 体等输出, 被湖体截留的磷均可能成为水体潜在内源磷. 以太湖为例, 太湖水体中通过反硝化等途径去除的 $\mathrm{TN}$ 约为太湖人湖河流输人 $\mathrm{TN}$ 的 $50 \%$ 左右 ${ }^{[36]}$. 因此, 从长期及湖体富营养化控制角度, 为了有效防止磷在 湖泊内的长期累积,开展人湖河流及其对应湖泊中磷的协同控制可能尤为重要.

我国幅员辽阔, 不同区域人湖河流对典型湖泊水体氮、磷水平和富营养化的影响程度可能存在较大差 异. 即使在同一区域不同类型湖泊, 人湖河流对湖体氮、磷水平及富营养的影响也可能存在较大差异. 以云 贵高原湖区典型湖泊为例 ( 图 4), 洱海、红枫湖均属于深水湖泊, 而滇池属于高原浅水湖泊. 人湖河流氮、磷 输人对深水湖泊和浅水湖泊氮磷水平的影响存在明显差异: 人湖河流氮、磷输人对浅水湖泊的影响显著, 而 对深水湖泊的影响程度较弱. 这可能是由于水深导致湖体内氮磷生物地球化学循环、自净能力和生物响应 等存在差异,浅水湖泊更易富营养化和暴发蓝藻水华 ${ }^{[37]}$.

人湖河流氮磷输人对湖泊水体水质和富营养化影响的决定性因素不仅仅是 TN、TP 浓度, 水量可能也是 重要因素之一. 以太湖为例, 2003 年以来, 环太湖主要人湖河流氮磷水质和人湖水量均发生了显著的变化. 基于太湖氮磷历史数据分析和文献研究报道 ${ }^{[38-39]}$, 实际上, 人湖河流 TN 、 TP 浓度的降低和“引江济太”等人 湖水量的增加, 均可以同时改善湖泊水体 TN TP 浓度及富营养程度. 然而, 环太湖主要人湖河流水质提升和 水量增加, 最终氮磷人湖负荷却未发生显著变化, 这可能是影响太湖富营养化和蓝藻水华仍频繁暴发的重 要因素之一. 基于湖泊水体 TN、TP 和富营养化改善目标, 太湖人湖水量增加和氮磷浓度降低的同时, 也进一 步协同调控并有效降低氮磷人湖总量, 在保证合理换水周期条件下, 使湖体 TN 、 TP 浓度水平降低 ${ }^{[39-40]}$. 因 此, 针对一些人湖水量变化较大的湖泊, 入湖河流与湖泊水体氮磷协同控制应该同时考虑人湖河流的氮磷 水质和水量,确保水质改善和水量调控对湖体富营养化改善起到更优效果 ${ }^{[41]}$.

\section{2 国际上关于入湖河流与湖泊水体氮磷协同控制的政策与案例}

水质基准是指环境中特定污染物对特定对象 (人或其他生物) 产生不良或有害影响的最大剂量或浓度, 
不具有法律效力 ${ }^{[42-45]}$. 同时,水体营养物基准的制定又与毒理学基准不同,需要综合考虑地理区域、水体类 型、基准指标、制定方法以及管理与评价等关键因素. 从河流与湖泊营养物基准制定的角度考虑, 二者在分 类方法、营养物主要指标和其他指标、数据分析和基准建立等方面均存在差异 ${ }^{[17]}$,因此二者获得的营养物基 准值可能存在较大差异. 水体营养物标准是以营养物基准为依据, 在考虑自然条件以及国家或地区的社会、 技术、经济等条件的基础上, 经过综合分析后制定的, 由国家有关管理部门或机关颁布,一般具有法律强制 性 ${ }^{[46]}$. 最终,河流、湖泊营养物基准与标准限值均存在一定差异,例如美国 EPA 推荐的不同生态分区河、湖 氮磷基准均存在一定差异,一些河流基准值甚至要严格于湖库水体基准值(表 5).

表 5 美国环境保护局推荐的部分营养物分区河、湖氮磷基准对比 ${ }^{[27-28]}$

Tab.5 Comparison of nitrogen and phosphorus criteria recommended by EPA between rivers and lakes in several ecoregions of the continental United States

\begin{tabular}{rcccccc}
\hline & & 生态区 $\mathrm{V}$ & 生态区 VI & 生态区 VII & 生态区VIII & 生态区 IX \\
\hline 湖库 & $\mathrm{TN} /(\mathrm{mg} / \mathrm{L})$ & 0.56 & 0.78 & 0.66 & 0.24 & 0.36 \\
河流 & & 0.88 & 2.18 & 0.54 & 0.38 & 0.69 \\
湖库 & $\mathrm{TP} /(\mu \mathrm{g} / \mathrm{L})$ & 33 & 37.5 & 14.75 & 8 & 20 \\
河流 & & 67 & 76.25 & 33 & 10 & 36.56 \\
\hline
\end{tabular}

国际上, 针对河流与湖泊营养物基准或标准限值存在差异, 制定了一些补充技术、政策措施或法律法规 等, 充分考虑了人湖河流、湖泊水体氮磷协同控制. 例如, EPA 现行的河流营养物制定的基准指南中针对人 湖河流指出流入静态水体 (包括湖泊) 的河流可能需要制定更为严格的营养物基准, 并在标准限值中体 现 ${ }^{[27]}$. EPA 现行湖泊、水库营养物制定基准指南中明确指出基于美国《清洁水法》303(d), 针对受损水体需 要开展每日最大负荷计划 (TMDLs) ${ }^{[28]}$, 并对上游水体执行更为严格、有实际效力的控制限值. 如果受损湖 泊为氮磷引起的富营养化和蓝藻水华问题, 按照美国《清洁水法》303(d) 要求, 为了修复受损湖泊需要制定 TMDLs 计划并按照削减计划对点源面源负荷进行直接控制和削减. 在 TMDL 计算过程中需要考虑人湖河流 氮、磷负荷, 但最终是基于湖泊水体营养物和叶绿素 $a$ 控制标准, 制定点源和面源的污染控制削减方案, 结 合内源治理等最终达到富营养化湖泊修复目的. 以美国明尼苏达州密西西比河源头区域 Little Turtle 湖和 Irving 湖营养物削减 TMDL 计划为例: Little Turtle 湖和 Irving 湖出现富营养化问题, 被纳人 EPA 受损水体清 单, 按照美国《清洁水法》303(d) 要求进一步制定具有实际效力的营养物削减 TMDL 计划 ${ }^{[47]}$. 该 TMDL 计划 方案制定过程中, 表明人湖河流和湖泊执行不同的 TP 标准是影响湖体富营养化和蓝㩰水华的重要原因 (表 $6,7)$, 即湖泊 TP 标准限值为 $30 \mu \mathrm{g} / \mathrm{L}$ 以下, 但是对应区域河流 TP 标准限值为 $50 \mu \mathrm{g} / \mathrm{L}$ 以下. 因此, 为了满 足湖体富营养化控制, 湖泊 TP 标准控制优先于河流标准控制. 基于区域富营养化标准, 以湖泊富营养化控 制为最终目标, 明尼苏达州污染控制局通过 HSPF 模型和 Bathtub 模型等制定了详细源头磷污染源控制 TMDL

表 6 明尼苏达州北部和森林生态区湖泊、浅水湖泊和水库营养物/富营养化标准 ${ }^{[47]}$

Tab.6 Nutrient/eutrophication criteria for lakes, shallow lakes and reservoirs in northern Minnesota and forest ecotope

\begin{tabular}{ccc}
\hline $\mathrm{TP} /(\mu \mathrm{g} / \mathrm{L})$ & $\mathrm{Chl} . a /(\mu \mathrm{g} / \mathrm{L})$ & 透明度 $/ \mathrm{m}$ \\
\hline$\leqslant 30$ & $\leqslant 9$ & $\geqslant 2.0$ \\
\hline
\end{tabular}

表 7 美国北部河流营养盐标准和总悬浮物标准 ${ }^{[47]}$

Tab.7 Nutrient standards and total suspended matter standards for rivers from northern USA

\begin{tabular}{ccccc}
\hline $\mathrm{TP} /(\mu \mathrm{g} / \mathrm{L})$ & $\mathrm{Chl} . a /(\mu \mathrm{g} / \mathrm{L})$ & 溶解氧 $/(\mathrm{mg} / \mathrm{L})$ & $\mathrm{BOD} /(\mathrm{mg} / \mathrm{L})$ & $\begin{array}{c}\text { 总悬浮颗粒物 } /(\mathrm{mg} / \mathrm{L}) \\
\text { (不超过 } 10 \% \text { 的时间 })\end{array}$ \\
\hline$\leqslant 50$ & $\leqslant 7$ & $\leqslant 3$ & $\leqslant 1.5$ & 15 \\
\hline
\end{tabular}


计划, 基于最终 TMDL 计划, 河流作为过渡区域, 理论上 TP 控制标准限值为 $29 \mu \mathrm{g} / \mathrm{L}$, 这个控制目标值甚至 要严格于区域湖泊水体 TP 的标准限值 $(\mathrm{TP} \leqslant 30 \mu \mathrm{g} / \mathrm{L})^{[47]}$.

\section{3 我国典型湖泊及入湖河流氮磷协同控制初步探讨}

基于本研究涉及的我国典型湖泊水体和人湖河流 TN、TP 浓度线性关系(图 2) 推算, 表明单独以《地表 水环境质量标准》( GB 3838- 2002) 规定限值控制这些典型湖泊人湖河流 TN、TP 浓度过于宽松 (表 8). 因 此, 针对人湖河流与湖泊氮磷协同控制, 需要其他配套措施、方案, 甚至制定区域、单个湖泊流域富营养化标 准体系等. 关于河湖协同控制问题, 张远等 ${ }^{[48]}$ 针对未来《地表水环境质量标准》修订的探讨中提出 “基于总 量控制方案, 由当地政府制定, 并衔接国家标准”. 在实际政策层面, 我国为了有效防止湖泊富营养化, 与《地 表水环境质量标准》(GB 3838-2002) 配套的《湖库富营养化防治技术政策》(环发[2004]) 于 2004 年发布, 并于 2017 年发布其修订版,在我国湖泊富营养化控制方面发挥了重要作用 ${ }^{[49]} .2017$ 年发布的《湖库富营养 化防治技术政策》(修订版) (环境保护部, 公告 2017 年 第 51 号), 基于国内外湖泊富营养化防治经验和教 训并结合国内外最新科技成果,其中“污染源治理” 部分明确提出 “根据湖 (库) 水生态功能、流域经济条件 和技术水平, 制定湖 (库) 及人湖 (库) 河流氮、磷分期质量标准和控制目标”. 除此之外, 我国一些其他技术 政策、规划、指南等也突出了人湖河流和湖泊氮磷协同控制. 例如, 《水质较好湖泊生态环境保护总体规划》 (2013-2020) 提出了分区保护策略, 要求对东部湖区和云贵高原湖区人湖河流 TN、TP 污染负荷进行削减 和控制. 2017 年, 水利部制定的《“一河 (湖)一策” 方案编制指南 (试行)》中, 要求人湖河流“一河一策”方案 要与湖泊方案衔接. 实践过程中, 我国对一些重点湖泊也单独开展了人湖河流氮磷协同控制的规划或方案 制定, 有效实施并取得实际效果. 例如, 针对太湖富营养化问题, 国家发展改革委员会实施的《太湖流域水环 境综合治理总体方案》、《太湖流域治理总体方案》(2013 年修编) 中基于湖体 TN、TP 控制目标, 明确规定了 主要人湖河流 TN、TP 控制目标浓度值, 甚至人河 (湖) TN、TP 污染负荷总量 ${ }^{[41]}$; 针对滇池富营养化和蓝藻 水华问题, 云南省也制定了《云南省水污染防治目标责任书》, 其中规定了滇池流域 18 条主要人湖河流的阶 段性 TN、TP 控制目标 ${ }^{[50]}$.

表 8 基于线性关系的我国典型湖泊人湖河流 TN、TP 协同控制目标值

Tab.8 Target values of TN and TP for collaborative control between typical lakes and their inflow rivers in China

\begin{tabular}{|c|c|c|c|c|}
\hline \multicolumn{2}{|c|}{$\mathrm{TN} /(\mathrm{mg} / \mathrm{L})$} & \multicolumn{3}{|c|}{$\mathrm{TP} /(\mathrm{mg} / \mathrm{L})$} \\
\hline GB 3838-2002 标准限值 & 推算控制目标值 & GB $3838-2002$ & 推算控制目标值 & GB 3838－2002 标准限值 \\
\hline 湖泊水体类别 (限值) & 人湖河流 & 湖体水体类别 (限值) & 人湖河流 & 河流 \\
\hline I 类 $(0.2)$ & - & $\mathrm{I}$ 类 $(0.01)$ & - & 0.02 \\
\hline II 类 $(0.5)$ & - & II 类 $(0.025)$ & 0.017 & 0.1 \\
\hline III类 (1) & 0.93 & III类 $(0.05)$ & 0.075 & 0.2 \\
\hline IV类(1.5) & 2.95 & IV 类 $(0.1)$ & 0.190 & 0.3 \\
\hline $\mathrm{V}$ 类 $(2)$ & 4.97 & $\mathrm{~V}$ 类 $(0.2)$ & 0.420 & 0.4 \\
\hline
\end{tabular}

从这些典型湖泊获得的统一的人湖河流氮磷协同控制目标值 (表 8 ) 来看, 显然对于不同湖区典型湖泊 人湖河流氮磷协同控制存在过于宽松或过于严格的情况 (表 2), 更无法适用于同一湖区内单个不同湖泊 (图 3,4). 以研究涉及东部平原湖区典型湖泊而言, 单独通过入湖河流氮磷协同控制, 多数湖泊可能无法达 到 III 类水质目标 (表 2), 这可能与流域背景、内源长期累积和释放、生态结构改变等密切相关. 这些典型湖 泊基本位于长江下游, ”十三五” 期间, 长江中下游干流 TP 浓度基本已经达到 $0.1 \mathrm{mg} / \mathrm{L}$ 左右 ${ }^{[51]}$. 因此,这些 东部平原湖区典型湖泊人湖河流 TP 控制显然要充分考虑流域背景、内源累积和释放等,设定合理的河湖氮 磷协同控制目标. 因此,结合国内外研究和我国已有的技术政策等, 以我国这些典型湖泊与其人湖河流氮磷 协同控制分析为基础,建议在考虑这些典型湖泊区域背景基础上,结合《地表水环境质量标准》,开展“一湖 一策” 的人湖河流氮磷协同控制. 在此基础上,一些水量变化大的湖泊流域人湖河流氮磷协同控制, 在传统 的氮磷浓度的基础上, 也应该关注不同水量下 $\mathrm{TN} 、 \mathrm{TP}$ 差异化协同控制, 或者建立水质、水量、通量等多控制 目标. 另外, 鉴于我国典型湖泊人湖河流磷的输人对湖泊水体磷水平和富营养化的影响较显著, 在大量湖泊 
流域数据分析和充分论证的基础上,建议优先尝试开展人湖河流和湖泊磷协同控制.

关于人湖河流与湖体氮、磷协同控制还需要进一步加强科学研究, 例如人湖河流输人氮磷形态变化等 对湖体氮、磷和富营养化的影响; 除了主要人湖河流以外,一些细小支流氮、磷长期输人对湖体氮、磷及富营 养贡献等 ${ }^{[13]}$. 另外, 《地表水环境质量标准》(GB 3838-2002) 要求水体样品采集 $30 \mathrm{~min}$ 后, 然后取上层非 沉降部分测定有关水质指标, 包括 TP. 该样品采集要求一定程度上有利于不同浊度水体样品之间的比较, 但是对水体样品中实际 TN、TP 的测定产生了较大的影响, 其中悬浮颗粒物 ( SS ) 是主要影响因素 ${ }^{[52-53]}$. 以三 峡水库干流江段水样为例, 当 $\mathrm{SS}$ 浓度大于 $500 \mathrm{mg} / \mathrm{L}$ 时, 水体样品中 $90 \%$ 以上的磷赋存于 $\mathrm{SS}$ 中. 然而, 按照 《地表水环境质量标准》( GB 3838-2002) 水样采集要求, 获得水体样品中 TP 仅代表了实际样品中 TP 浓度 的 $50 \%$ 以下 ${ }^{[53]}$. 因此, 人湖河流、湖体在不同水动力条件下, 二者颗粒态磷浓度差异大, 通过该方法获得数 据进行对比分析, 可能无法较好地反映人湖河流对湖体氮、磷和富营养化实际影响程度. 因此, 建议考虑《地 表水环境质量标准》(GB 3838-2002) 水样采集方式对人湖河流和湖体水体样品氮磷定量分析的影响及其 规律,并通过定量反推等方式反映在人湖河流氮、磷控制目标上.

\section{4 结论}

基于”十三五” 期间我国一些典型湖泊及对应人湖河流 TN、TP 监测数据对比分析, 并结合 2003-2018 年期间太湖及其主要人湖河流 TN TP、入湖水量和人湖负荷对比分析, 结合国际上人湖河流和湖泊氮、磷协 同控制, 以及《地表水环境质量标准》(GB 3838-2002) 和相关配套政策、措施等, 针对这些典型湖泊及其对 应人湖河流获得主要结论和政策建议如下：

1) 人湖河流氮磷水平仍然是我国一些典型湖泊水体氮、磷水平和富营养化程度的重要影响因素之一, 其中 TP 输人对湖泊水体 TP 的影响较大, 对湖体富营养化程度的影响更显著, 开展人湖河流及其对应湖泊 中磷的协同控制可能尤为迫切.

2) 我国一些典型湖泊氮磷水平和富营养化程度单纯依靠人湖河流氮、磷控制已经无法较好地达到 III 类 水及以下水平,中营养化水平及以下,建议结合内源控制、生态修复等综合治理.

3) 统一的人湖河流氮磷协同控制目标值对于不同湖区典型湖泊人湖河流氮、磷协同控制存在过于宽松 或过于严格的情况, 更无法适用于单个不同湖泊. 因此, 建议在考虑这些典型湖泊区域背景的基础上,开展 “一湖一策”的人湖河流氮磷协同控制.

4) 人湖河流水量也是湖泊水体氮磷水平和富营养化程度重要因素之一. 一些水量变化大的典型湖泊流 域人湖河流氮磷协同控制,在传统的氮、磷浓度的基础上,也应该关注不同水量下 TN、TP 差异化协同控制, 或者建立水质、水量、通量等多控制目标.

\section{5 参考文献}

[ 1 ] Ma RH, Yang GS, Duan HT et al. China's lakes at present: Number, area and spatial distribution. Scientia Sinica: Terrae, 2011, 41(3) : 394-401. [马荣华, 杨桂山, 段洪涛等. 中国湖泊的数量、面积与空间分布. 中国科学: 地球科 学, 2011, 41(3): 394-401.]

[ 2 ] International Lake Environment Committee (ILEC) ed. Managing lakes and their basins for sustainable use: A report for lake basin managers and stakeholders. Kusatsu: International Lake Environment Committee foundation, 2005.

[ 3 ] Schindler DW. Recent advances in the understanding and management of eutrophication. Limnology and Oceanography, 2006, 51(1part2) : 356-363. DOI: 10.4319/lo.2006.51.1_part_2.0356.

[ 4 ] Yang GS, Ma RH, Zhang L et al. Lake status, major problems and protection strategy in China. J Lake Sci, 2010, 22 (6) : 799-810. DOI: 10.18307/2010.0601. [ 杨桂山, 马荣华, 张路等. 中国湖泊现状及面临的重大问题与保护策 略. 湖泊科学, 2010, 22(6): 799-810.]

[ 5 ] Fink G, Alcamo J, Flörke M et al. Phosphorus loadings to the world's largest lakes: Sources and trends. Global Biogeochemical Cycles, 2018, 32(4) : 617-634. DOI: 10.1002/2017GB005858.

[ 6 ] Correll DL. The role of phosphorus in the eutrophication of receiving waters: A review. Journal of Environmental Quality, 1998, 27(2) : 261-266. DOI: 10.2134/jeq1998.00472425002700020004x. 
[ 7 ] Wu FC, Jin XC, Zhang RY et al. Effects and significance of organic nitrogen and phosphorous in the lake aquatic environment. J Lake Sci, 2010, 22(1) : 1-7. DOI: 10.18307/2010.0101. [吴丰昌, 金相灿, 张润宇等. 论有机氮磷在湖泊 水环境中的作用和重要性. 湖泊科学, 2010, 22(1): 1-7.]

[ 8 ] Tong YD, Zhang W, Wang XJ et al. Decline in Chinese lake phosphorus concentration accompanied by shift in sources since 2006. Nature Geoscience, 2017, 10(7) : 507-511. DOI: 10.1038/ngeo2967.

[ 9 ] Qin BQ, Yang LY, Chen FZ et al. Mechanism and control technology of lake eutrophication and its application. Chinese Science Bulletin, 2006, 51(16): 1857-1866. [秦伯强, 杨柳燕, 陈非洲等. 湖泊富营养化发生机制与控制技术及其 应用. 科学通报, 2006, 51(16): 1857-1866.]

[10] Zhu GW, Xu H, Zhu MY et al. Changing characteristics and driving factors of trophic state of lakes in the middle and lower reaches of Yangtze River in the past 30 years. J Lake Sci, 2019, 31(6) : 1510-1524. DOI: 10.18307/2019.0622. [朱 广伟, 许海, 朱梦圆等. 三十年来长江中下游湖泊富营养化状况变迁及其影响因素. 湖泊科学, 2019, 31(6): 1510-1524.]

[11] Wu FC, Wan GJ, Cai YR. Biogeochemical processes at the sediment-water interface. Advance in Earth Sciences, 1996,11 (2) : 191-197. [ 吴丰昌, 万国江, 蔡玉蓉. 沉积物-水界面的生物地球化学作用. 地球科学进展, 1996, 11(2): 191-197.]

[12] Wu FC, Wan GJ, Huang RG. Biogeochemical processes of nutrition elements at the ediment-water interface of lakes I . nitrogen cycling and its environmengal inpacts. Acta Mineralogica Sinica, 1996, 16(4) : 403-409. [吴丰昌, 万国江, 黄荣 贵. 湖泊沉积物-水界面营养元素的生物地球化学作用和环境效应 I. 界面氮循环及其环境效应. 矿物学报, 1996, 16(4) : 403-409.]

[13] Mooney RJ, Stanley EH, Rosenthal WC et al. Outsized nutrient contributions from small tributaries to a Great Lake. Proceedings of the National Academy of Sciences of the United States of America, 2020, 117(45) : 28175-28182. DOI: 10. 1073/pnas.2001376117.

[14] Wang H, Chen HX, Xu ZA et al. Variation trend of total phosphorus and its controlling factors in Lake Taihu, 2010-2017. J Lake Sci, 2019, 31(4) : 919-929. DOI: 10.18307/2019.0421. [王华, 陈华金金, 徐兆安等. 2010-2017 年太湖总磷 浓度变化趋势分析及成因探讨. 湖泊科学, 2019, 31(4): 919-929.]

[15] Wetzel RG. 13-the phosphorus cycle. In: Wetzel RG ed. Limnology (third edition). San Diego: Academic Press, 2001 : 239-288.

[16] Lottig NR, Stanley EH, Hanson PC et al. Comparison of regional stream and lake chemistry: Differences, similarities, and potential drivers. Limnology and Oceanography, 2011, 56(5) : 1551-1562. DOI: 10.4319/lo.2011.56.5.1551.

[17] Xi BD, Huo SL, Su J eds. Introduction to theory and methodology of nutrient criteria. Beijing: Science Press, 2016. [ 席北 斗, 霍守亮, 苏婧. 水体营养物基准理论与方法学导论. 北京: 科学出版社, 2016.]

[18] Wu FC, Meng W, Song YH et al. Research progress in lake water quality criteria in China. Acta Scientiae Circumstantiae, 2008, 28 (12) : 2385-2393. [ 吴丰昌, 孟伟, 宋永会等. 中国湖泊水环境基准的研究进展. 环境科学学报, 2008, 28 (12) : 2385-2393.]

[19] US EPA ed. National strategy for the development of regional nutrient criteria. Washington DC: United States Environment Protection Agency, 1998.

[20] Water Framework Directive-United Kingdom Advisory Group (WFD-UKTAG). UKTAG Lake Assessment Method Phosphorus-Lake Phosphorus Standards, 2016.

[21] Water Framework Directive-United Kingdom Advisory Group (WFD-UKTAG). UKTAG Lake Assessment Method Phosphorus-River Phosphorus Standards, 2016.

[22] Environment and Climate Change Canada ed. Canadian environmental sustainability indicators: Nutrients in Lake Winnipeg, Cat. No.: En4-144/70-2018E-PDF, ISBN : 978-0-660-27807-0, 2018.

[23] Environment and Climate Change Canada ed. Canadian environmental sustainability indicators: Water quality in Canadian rivers, Cat. No.: En4-144/64-2019E-PDF, ISBN : 978-0-660-29291-5, 2019.

[24] Zhang SB. The reasonable standard of nitrogen and phosphorus content in lake Water stipulated by Japan. Journal of AgroEnvironmental Science, 1984, 3(1) : 26. [张声榜. 日本规定湖水中氮、磷含量的合理标准. 农业环境科学学报, $1984, \mathbf{3}(1): 26$.

[25] Liu F, Wang SR, Li GB et al. Water pollution of and environmental protection \& management of lakes in South Korea. Wa- 
ter Resources Development Research, 2015, 15(6): 64-68. [刘芳, 王圣瑞, 李贵宝等. 韩国湖泊水污染特征与水环境 保护管理. 水利发展研究, 2015, 15(6): 64-68.]

[26] Mackenthun KM. Eutrophication and biological associations. In: Griffith EJ, Beeton A, Spencer JM et al eds. Environmental phosphorus handbook. New York: Wiley, 1973: 613-632.

[27] US EPA ed. Nutrient criteria technical guidance manual: River and streams. Washington DC: United States Environmental Protection Agency, Office of water, Office of Science and Technology. EPA-822-B-00-002, 2000.

[28] USEPA ed. Nutrient criteria technical guidance manual: Lakes and reservoirs. Washington DC: United States Environmental Protection Agency, Office of water, Office of Science and Technology. EPA-822-B-00-001, 2000.

[29] Xu C, Wan RR, Ma Q et al. The research in the revised plan of water quality standard of the nitrogen and phosphorus for the inflow rivers in the northwest of the Taihu Lake. Resources and Environment in the Yangtze Basin, 2017, 26( 8) : 11801188. DOI: 10.11870/cjlyzyyhj201708008. [许晨, 万荣荣, 马倩等. 太湖西北部湖区人湖河流氮磷水质标准修正方 案研究. 长江流域资源与环境, 2017, 26(8) : 1180-1188.]

[30 ] Wang ZW, Lin JN, Zhang Y et al. Water quality limits of nitrogen and phosphorus in the inflow rivers of Poyang Lake. Research of Environmental Sciences, 2020, 33(5): 1163-1169. [王子为, 林佳宁, 张远等. 鄱阳湖人湖河流氮磷水质控 制限值研究. 环境科学研究, 2020, 33(5): 1163-1169.]

[31] Lv W, Sun RR, Wang C et al. Study on the control standards of nitrogen and phosphorous nutrients in west Lake Yangcheng's main inflow rivers. Water Conservancy Science and Technology and Economy, 2018, 24(4) : 1-4. [吕文, 孙 瑞瑞, 王诚等. 基于 BATHTUB 模型的阳澄西湖人湖河道氮磷营养盐控制分析. 水利科技与经济, 2018, 24(4): 1-4. ]

[32] Cheng ST, Qian YC, Zhang HJ. Estimation and application of macroscopic water environmental capacity of total phosphorus and nitrogen for Taihu Lake. Acta Scientiae Circumstantiae, 2013, 33(10): 2848-2855. DOI: 10.13671/j. hjkxxb. 2013.10.032. [程声通, 钱益春, 张红举. 太湖总磷、总氮宏观水环境容量的估算与应用. 环境科学学报, $2013, \mathbf{3 3}$ (10) : 2848-2855.]

[33] Yi J, Xu F, Gao Y et al. Variations of water quality of the major 22 inflow rivers since 2007 and impacts on Lake Taihu. $J$ Lake Sci , 2016, 28(6) : 1167-1174. DOI: 10.18307/2016.0602. [易娟, 徐枫, 高怡等. 2007 年以来环太湖 22 条主 要河流水质变化及其对太湖的影响. 湖泊科学, 2016, 28(6): 1167-1174.]

[34] Ma P, Li XY, Wang HX et al. Denitrification and its role in cycling and removal of nitrogen in river. Journal of Agro-Environment Science, 2014, 33(4) : 623-633. DOI: 10.11654/jaes.2014.04.002. [马培, 李新艳, 王华新等. 河流反硝化 过程及其在河流氮循环与氮去除中的作用. 农业环境科学学报, 2014, 33(4)：623-633.]

[35] Baker MA, Arp CD, Goodman KJ et al. Chapter 7 - Stream-lake interaction: Understanding coupled hydro-ecological systems. In: Jones JB, Stanley EH eds. Stream ecosystems in a changing environment. Boston: Academic Press, 2016: 321-348.

[36] Chen XF, Chuai XM, Zeng J et al. Nitrogenous fluxes and its self-purification capacity in Lake Taihu. Chinese Journal of Environmental Science, 2012, 33(7) : 2309-2314. [陈小锋, 揣小明, 曾巾等. 太湖氮素出人湖通量与自净能力研究. 环境科学, 2012, 33(7): 2309-2314.]

[37] Qin BQ, Zhou J, Elser JJ et al. Water depth underpins the relative roles and fates of nitrogen and phosphorus in lakes. Environmental Science \& Technology, 2020, 54(6) : 3191-3198. DOI: 10.1021/acs.est.9b05858.

[38 ] Yan SW, Yu H, Zhang LL et al. Water quantity and pollutant fluxes of inflow and outflow rivers of Lake Taihu, 2009. J Lake Sci, 2011, 23(6): 855-862. DOI: 10.18307/2011.0605. [燕姝雯, 余辉, 张璐璐等. 2009 年环太湖人出湖河流 水量及污染负荷通量. 湖泊科学, $2011,23(6): 855-862$. ]

[39] Wang XM, Zhai SH, Zhang HJ et al. Research on appropriate hydraulic retention time on basis of water quality improvement of Lake Taihu. J Lake Sci, 2017, 29(1)：9-21. DOI: 10.18307/2017.0102. [王冼民, 翟淑华, 张红举等. 基于 水质改善目标的太湖适宜换水周期分析. 湖泊科学, 2017, 29(1):9-21.]

[40] Yuan HZ, Chen JH. Analysis of the allowed pollution load into Taihu Lake under different water quantities. Journal of Irrigation and Drainage, 2015, 34 (S1) : 147-151. [袁洪州, 陈江海. 不同人湖水量条件下太湖允许人湖污染负荷量分 析. 灌溉排水学报, 2015, 34(S1) : 147-151.]

[41] The National Development and Reform Committee. The Taihu Lake basin management, 2013. http://www.tba.gov.cn/ slbthlyglj/.[发展改革委员会. 太湖流域治理总体方案, 2013.] 
[42] US EPA ed. Ambient water quality criteria ( series). Technical report. Washington DC: US EPA, 1980.

[43] US EPA ed. Quality criteria for water. Technical report. Washington DC: Office of Water Regulations and Standards, 1976.

[44] US EPA ed. Quality criteria for water. Technical Report. Washington DC: Office of Water Regulations and Standards, 1986.

[45] Feng CL, Wu FC, Zhao XL et al. Research and progress on water quality benchmark. Scientia Sinica: Terrae, 2012,42 (5): 646-656. [冯承莲, 吴丰昌, 赵晓丽等. 水质基准研究与进展. 中国科学: 地球科学, 2012, 42 (5): 646-656.]

[46] Ji DF, Su J, Xi BD et al. The method of transforming lake nutrient criteria into standards in foreign countries and the enlightenment to China. Journal of Environmental Engineering Technology, 2012, 2(3) : 229-233. [纪丹凤, 苏婧, 席北斗 等. 国外湖泊营养物基准向标准转化方法对我国的启示. 环境工程技术学报, 2012, 2(3): 229-233.]

[47] Best B, Rudd B, Balmes S et al. Mississippi headwaters total maximum daily loads for Little Turtle Lake and Lake Irving. Mississippi Headwaters TMDL Report, Minnesota Pollution Control Agency, 2018.

[48] Zhang Y, Lin JN, Wang H et al. Research on environmental quality standard for surface water. Research of Environmental Sciences, 2020, 33(11) : 2523-2528. [张远, 林佳宁, 王慧等. 中国地表水环境质量标准研究. 环境科学研究, $2020,33(11): 2523-2528$.

[49] Guo W, Liu XX. A classification strategy for prevention and control of eutrophic lakes and reservoirs. China Environment News, 2017-10-16(006). [ 郭薇, 刘晓星. 指导富营养化湖库分类防治. 中国环境报, 2017-10-16(006).]

[50] General Office of the People's Government of Yunnan Province. Water pollution prevention and control work plan in yunnan province, 2016. http://www.yn.gov.cn/zwgk/zcwj/zxwj/202005/t20200527_204615.html. 2016. [云南省人民政府办 公厅.云南省水污染防治工作方案, 2016.]

[51] Chen SR, He LH, Zhang FY et al. Spatiotemporal characteristics of surface water quality of the Yangtze River Basin during 2016-2019. Research of Environmental Sciences, 2020, 33(5) : 1100-1108. [ 陈善荣, 何立环, 张凤英等. 2016-2019 年长江流域水质时空分布特征. 环境科学研究, 2020, 33(5): 1100-1108.]

[52] Li X, Luo CH, Zhang ZY et al. Study on the effect of static balance time on determination of total phosphorus in surface water. Environmental Monitoring in China, 2005, 21(2): 22-23. [李晓, 罗财红, 张筑元等. 地表水样品自然沉降时 间对总磷测定结果的影响分析. 中国环境监测, 2005, 21(2): 22-23.]

[53] Lou BF, Zang XP, Hong YP et al. The effect of sample pretreatment on determination of total phosphorus in water. Acta Scientiae Circumstantiae, 2006, 26(8): 1393-1399. [娄保锋, 藏小平, 洪一平等. 水样不同处理方式对总磷监测值 的影响. 环境科学学报, 2006, 26(8): 1393-1399.] 